\title{
Developing of Entrepreneur Digitals Learning Model in the Industrial Revolution 4.0 to Improve $21^{\text {st }}$ Century skills
}

\author{
Erdisna, Ganefri, Ridwan, Raimon Efendi
}

\begin{abstract}
This study aims to develop a learning model of Information System Design Analysis in Vocational Education that is valid, effective and practical. Based on preliminary studies and needs analysis conducted on the Information Systems Design Analysis course, it was found that learning is not optimal. The needs analysis also found that there were privices / needs of lecturers and students who had high expectations of the learning process that were able to improve 21st century competence, i.e. This type of research is Research and Development which refers to the 4D model. The analysis technique uses the Aiken' $V$ test, and validity uses expert testing and Focus Group Discussion (FGD). The research findings are an Entrepreneur Digitals Learning Model (ERDIS) that is equipped with model books, teaching material books, lecturer manuals and student manuals. Models and support systems meet the validity criteria, are based on research and development models and are suitable for use by experts. The results of testing the validity of the results show that all products already have the results of product validity are at a score $>0.677$. The results of testing the practicality of the product according to students $82 \%$, based on the perception of lecturers 85\% means the product has a high practicality. The results of the analysis of the effectiveness of the cognitive domain showed a t-test score of 3,252> t table of 2.010 which means that Hypothesis (Ha) was accepted, the affective domain hypothesis testing showed a t-count score of 3,688> t table of 2,010 which meant that Hypothesis (Ha) at the 95\% significance level . The results of research in the psychomotor domain through the evaluation of ERDIS 1 and 2 projects are in the Good category, this means that the products are valued for effectiveness
\end{abstract}

Keywords : Developing Model learning, ERDIS, $R$ and $D$, Entrepreneur Digitals Learning

\section{INTRODUCTION}

The 21st century learning paradigm emphasizes the ability of students to find out from various sources, formulate problems, think analytically and collaboratively and collaborate in solving problems [1]. The challenges due to the changing view of education in the 21st century agree with

Revised Manuscript Received on February 05, 2020.

* Correspondence Author

Erdisna*, is student at Fakultas Teknik, Universitas Negeri Padang, email : erdisna@gmail.com

Ganefri, is lecturer at Fakultas Teknik, Universitas Negeri Padang, email :ganefri1@gmail.com

Ridwan, is lecturer at Fakultas Teknik, Universitas Negeri Padang, email : ridwanharun@ yahoo.com

Raimon Efendi, is lecturer at Faculty of Computer Science, Universitas Dharmas Indonesia, email : raimon.efendi@gmail.com

(C) The Authors. Published by Blue Eyes Intelligence Engineering and Sciences Publication (BEIESP). This is an open access article under the CC BY-NC-ND license (http://creativecommons.org/licenses/by-nc-nd/4.0/)
Joseph Schumputer, an entrepreneurial expert in the world who states that entrepreneurship is an engine of world economic power, therefore integration and creation of innovations in industrial units is needed as a result of the development of machines in technology [2]. Creating entrepreneurship in the face of technology will seek sources of economic power in countries throughout the world. Entrepreneurship is the economic strength of a country, thus the formation of entrepreneurial character in the education process must be a concern in order to achieve excellence in 21st century competition [3].

The frameworks of 21st century learning are Critical-Thinking and Problem-Solving Skills, Communication and Collaboration Skills, Critical-Thinking and Problem-Solving Skills, Communication and Collaboration Skills, Creativity and Innovation Skills, Information and Communications Technology Literacy, Contextual Learning Skills, and Media information and literacy skills. Based on the results of the analysis at the time of successful knowledge

Integrating information and knowledge derived from some general characteristics and implementing learning that can be done in the 21st century. The transition of learning in the industrial period to the knowledge age, as for these changes as follows: first, a paradigm shift in educational practice [4]. Many learning in the industrial age is in contrast to the learning of the knowledge age, where learning based on facts, drills and practices is very effective for learning the industrial age, but in the industrial era learning becomes project based learning and problem problem based, inquiry and discovery. In the age of knowledge (knowledge age) as if everything depends on information technology and computing, but there are some things on learning that can be carried out without using that technology. Although information and communication technology is an important catalyst for transferring learning from the industrial age to the knowledge age, it is not a tool for determining outcomes in the learning process. Development of learning models in the world of education is continuously carried out to improve the quality of learning from the educational process itself, both formal and non-formal education [5]. This effort is in line with the development of science and technology that occurs in the midst of society. The development of science and technology will have an impact on the order of human life on this earth and become a challenge for every individual to compete in it, especially in the field of work [6].

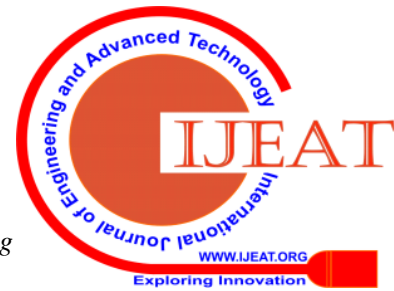


For the world of education, this phenomenon requires the world of education to adapt to this existence to improve the quality of education in order to produce a professional workforce in filling existing jobs with competent human resources in their fields [7]. Changes in the order of life in this globalization era indirectly influence the reference and formulation of competencies that have been prepared in the Education curriculum. Especially the vocational higher education curriculum or vocational education traning (VET). As a provider of Human Resources (HR) graduates at the professional level needed by the community with the philosophy of "ready to use labor". This is in accordance with the objectives of vocational education in pragmatic terms is to meet individual needs for personal fulfillment and life preparation which is characterized by an emphasis on solving problems and thinking at a higher level, and the purpose of vocational education in terms of reconstruction pragmatism is to change work to be more democratic, more proactive, fight against injustice and inequality in work problems [8].

The fact to answer the question of the challenges of the world in the face of the industrial revolution 4.0 makes observers and practitioners of Vocational education must be more detailed in developing new skills that are adapted to the learning needs of the globalization era adjusting to the new literacy era of the industrial revolution 4.0. Experts predict that changes in work patterns will continue to occur more quickly. The impact of the industrial revolution 4.0 on the state, society, industry and companies is speed, breadth and depth, with the systemic impact of inequality being the biggest challenge. For this reason, this paper will discuss New Literacy in the formulation of competencies for vocational higher education as a step to change the formulation of innovations in vocational higher education [9]. The new literacy movement is intended to focus on three main literacies namely, 1) digital literacy, 2) technological literacy and 3) human literacy. These three skills are predicted to be skills that are highly needed in the future or in the era of the industrial revolution 4.0. The new literacy provided is expected to create competitive graduates by perfecting the old literacy movement which only focuses on improving reading, writing and mathematics skills. Four strategic steps in dealing with Industry 4.0. stated by the Indonesian Ministry of Industry, namely 1) Encouraging the workforce in Indonesia to continue to improve capabilities and skills, especially in using internet technology and integrating internet capabilities with production lines in industry, 2) Utilization of digital technology to spur productivity and competitiveness for industry small and medium scale (IKM) to be able to penetrate the export market through the E-smart IKM program, 3) Utilization of digital technology that is more optimal in national industries such as Big Data, Autonomous Robots, Cybersecurity, Cloud, and Augmented Reality, 4) Encouraging technological innovation through start up development by facilitating business incubation so that more technology-based entrepreneurs in the territory of Indonesia.

Technology literacy is a capability that is in the form of combining several abilities in recognizing, processing and using and evaluating technology so that a person can have a more integrative awareness and quality related to the distribution of skills and competencies in the context of duties and obligations to the community. Because for the development of various skills needed, students can understand the scope of information channels and resources to gain confidence in having the accuracy, reliability, and accuracy of information obtained, having greater control over their own ability to learn. Currently the implementation of education in Indonesia has been referring to the direction of world education oriented to 21st century learning [10]. As a result of demands for changes in the direction of education laden with the opening of global competition as a result of the flow of information technology and the existence of the internet. Unlimited information causes global competition which makes Indonesian HR have to compete with HR without knowing their country of origin [11]. Therefore improving the quality of human resources adjusts to the needs of knowledge-based 21st century human resources for the demands to be professional [12]. The burden in developing curriculum based on the ability to become a reliable and professional human resource in mastering a source of knowledge causes the educational process to innovate and develop efforts to implement creative education. Educators are responsible for developing students' skills and competencies through efforts to prepare students to have global skills [7]. BNSP (2010) states that some of the global skills that must be possessed by Indonesian HR are 1) critical thinking and problem solving skills, 2) communication and collaboration skills, 3) creation and skills updating (creativity and innovation skills), 4) information and communication technology literacy, 5) contextual learning skills, 6) cooperative literacy skills in utilizing multimedia and communication (media literacy skills). Technology is a formative part of society and is an important factor in life today, both for individuals and for professionals. Technology has an influence on the economy, environment, culture, health, ensuring sustainable development and becoming a center of innovation in a profession. Technology responds to fundamental social challenges and provides mobility, communication and innovation, technology changes human habits, lifestyles and work processes that are both a blessing and a burden on human life [13] . Undeniable technology holds a key position for social change and determines how a person and a group of people view themselves and the world. Technology literacy is "The ability of a person to work independently or cooperate with others effectively, responsibly and appropriately by using technological instruments to obtain, manage, then integrate, evaluate, create and communicate information". Technology literacy and communication media in the 21st century rainbow skills scheme proposed by Trilling and Fadel [14] consists of; 1). Information literacy in which students are able to access information effectively information sources and time efficient; evaluating information that will be used critically and competently; use and manage information accurately and effectively to solve problems. 2) Media literacy: students are able to choose and develop media used to communicate. 3) ICT Literacy: students are able to analyze information media; and creating appropriate media for communication.

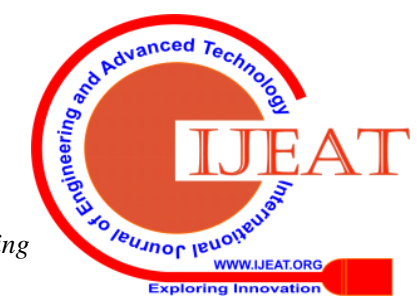


The goal of sustainable development stated by UNESCO [13] in the Lifelong Learning chart which was formulated as a guide to the sustainable development agenda aimed at meeting the demands of global leadership, there are four competencies related to how students can face complex challenges with four abilities namely Critical thinking, Creativity, Communication and Collaboration. These four abilities are indicators for a human being believed to be humanly able to conquer the challenges of the 21st century, these four abilities are called 4C competencies [15].

The main reason for developing the learning model of entrepreneurship in digital diera based on the new literacy era of the industrial revolution 4.0 is the emergence of the need for college graduates to be able to survive the digital diera by having a new competency set to be able and skilled to become a professional who has critical and creative thinking as a driver of the digital diera industry. In addition, the emergence of the problem of weakening human interaction with fellow human beings as a bias from the use of technology that limits communication and collaboration between fellow human beings is also a matter of concern and finding a way out through a learning process that is laden with the cultivation of attitudes of interaction between fellow human beings. Another reason that is no less important is the emergence of new opportunities in digital diera with the internet of things that cause students to prepare themselves through innovative education based on the new literacy industry revolution 4.0 based on realistic activities in real life to hone the sensitivity of students to recognize the problems in their environment alone. The solution that can be offered as a result of this change is to integrate entrepreneurship learning in the digital era based on the new literacy era of the industrial revolution 4.0 in the form of a project in accordance with real life. The development of the learning model undertaken is in agreement with Drake, S.M. [16]states that by integrating cognitive learning and skills into the curriculum of learners can gain a deeper understanding of the subject and try to solve complex problems that occur in the real world. This is a reinforcement that through integrated learning in the real world and solving real-world problems, there will be a leadership spirit in problem solving, able to work well in teams, the ability to read, analyze, and use information. Therefore the relevance between education and work needs to be adjusted to the development of science and technology by taking into account aspects of humanities.

Through this developed model, students can collaborate abilities among group members, through good cooperation. It is hoped that through the ERDIS (Entrepreneur Digitals) learning model of the Industrial Revolution Era 4.0 student creativity will be further increased. It is expected that with the development carried out this can encourage the fulfillment of the need to achieve competitiveness of 21st century students who have superior entrepreneurial character.

\section{RESEARCH METHOD}

This research is a development research that uses Research and Development (R \& D) design. Research and Development is a research model used to produce certain products, and test the effectiveness of these products [17]. This development research was designed to produce a product that is in the form of an authentic assessment instrument in Network Learning Course. This development research product uses 4D models consists of four phases (Define, Desing, Develop hingga Disseminate).

The instruments used in this study are validation instruments, practicality instruments, and effectiveness instruments[18], [19]. The technique of collecting qualitative data is done by interview, observaion and study documentation[20]-[22]. The validity of qualitative data credibility; the term used in qualitative research to replace the concept of validity on quantitative data is tested. Data credibility can be maintained by using several criteria of examination techniques, namely: 1) extension of the researcher's participation in the field, 2) increasing observational persistence, 3) triangulation [23]. The quantitative data is analyzed by descriptive statistics, while qualitative data is analyzedand preswnted with reduction, display, and conclusions [24].

The type of data in this study is primary data that is data obtained directly from validators (experts), lecturers and students taken through a questionnaire testing the validity, practicality and effectiveness of the model.

Material validation data was obtained from instruments filled out by validators who were education experts. Material practicality data was obtained from observer assessments that observed learning activities conducted by lecturers and students. The number of students who take part in the research is in accordance with student attendance.

Data on the effectiveness of teaching material was obtained from the cognitive, affective and psychomotor abilities of students about cognitive abilities which were carried out by comparing the cognitive abilities of students in the Analysis of Information System Design of the experimental group and the control group. Affective and psychomotor aspects were assessed by analyzing the ability of students only in the experimental group.

\section{RESULTS AND DISCUSSION}

Data description of the results of the study revealed the procedures and results of the development that had been carried out based on the development steps used. The research and development procedures carried out in this study use the Four D's design with Define, Design, Develop and Disseminate stages, for this reason the following description of the research results:

\section{A. Define}

Define is the first step in developing using the Four D's development design. at this stage an analysis of development needs is carried out with the description of the following steps:

\section{Front-end analysis}

Stages of researchers conducting studies of the fundamental problems faced by educators that cause low performance and achievement of educational outcomes. Analysis of the problem in this study was conducted to find out the fundamental problems with APSI learning at UPI YPTK Padang. Analysis of the situation in the field shows the fact that educators have difficulty achieving optimal learning outcomes based on the ability of students to develop applications (software).

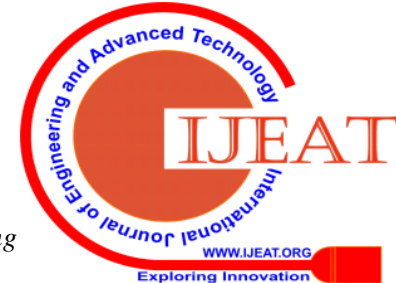


Products developed by students who have difficulty in developing them only cost money to produce an application.

While it is known that the achievement of student learning success in vocational education is determined by how students can provide the needs of the community in applying their knowledge, that the educational process in vocational education will optimally achieve goals if adjusted to the needs of the community in the link and match the results of education by user needs. While the problem that arises is that students are only able to achieve learning outcomes in the form of learning outcomes, but are still low in the application and use of their abilities in society. Software Feasibility Test data conducted indicate that the use of software developed by students is still low. Data can be seen in figure 1 .

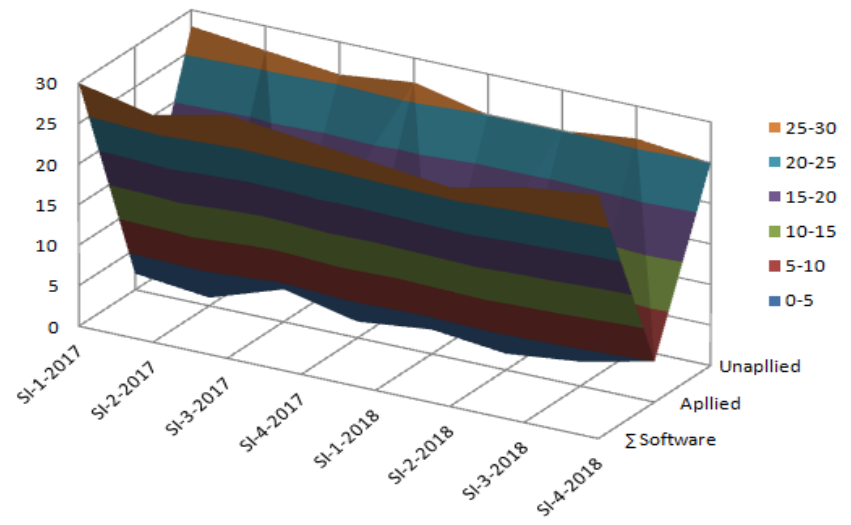

Fig 1. Results of Student Software Feasibility Test

Based on the data in table 1, it was concluded that in the odd semester of 2017 students only had an average software usage of $7.69 \%$ and in the odd semester of 2018 only had an average software usage of $11.4 \%$. This means that very little of the application software developed by students has passed the feasibility test which means that the software does not meet the user's needs. This indicates that it is necessary to develop a learning model that can optimize the achievement of learning outcomes in vocational education goals.

\section{Need Analysis}

This stage is an act where the researcher conducts a study of students who become the target of training in identifying the characteristics of students that are relevant to the design and instructional development that will be carried out. Based on the results of the needs analysis on the expectations and desires of students in learning APSI courses, it was found that students have an interest and needs in learning APSI. Based on the needs analysis that has been done, it can be explained that the analysis of the needs of students to study APSI is in the high category with an average score of $82 \%$. This means that students have an interest in learning APSI, therefore development should be carried out to improve learning outcomes so that students' needs for APSI learning can be met.

\section{Task analysis}

The task of researchers conducted at this stage is to conduct empirical analysis to identify the main skills acquired by students and their analysis into a set of subskill required. Based on the 21st century learning phenomenon that is the cause of the emergence of learning innovations adjusting the competencies or abilities needed to compete in the 21st century so as to emerge the demands of quality human resources who have competitive competencies that are in harmony with the entrepreneurial spirit as superior characters. Then with the need for integrated learning processes in higher education with the ability to apply mind sets and entrepreneurial character as contained in 21st century competencies, educators need to innovate in learning. Higher education requires graduates who have superior entrepreneurial character and are able to compete as entrepreneurs in accordance with their scientific competencies with mastery of the new literacy era of the industrial revolution 4.0 consisting of 1 ) big data literacy, 2) technological literacy, and 3) humanity literacy. Therefore, the development carried out is to improve the ability of students in these three literacies through digital entrepreneurial activities.

\section{Concept analysts}

The act of identifying the main lessons that must be taught are related to the learning objectives that are developed. Concept analysis is used to formulate learning objectives. The results of the concept analysis in this development formulating the description and learning objectives of APSI using the ERDIS learning model are "Students are able to carry out digital entrepreneur projects designing information systems using structured approach aids; ASI, DFD, ERD by applying the new literacy capabilities of the industrial revolution era 4.0 ".

\section{B. Design}

The activities carried out at the Design stage are described as follows:

\section{Constituting criterion referenced tests}

The phase in which the educator compiles the specified test criteria / standards. This stage is the link between Stage 1 (Define) and the Design Process.

The preparation of the test criteria is based on Task Analysis (Define) referred to by the reference, the educator develops by changing the objectives into an outline of teaching for the development of teaching materials. Associated with the APSI learning curriculum, it can be explained the competencies that must be obtained by students in APSI learning and compiled in Learning Activity (data attached). In the APSI learning design using Digital Entrepreneur learning mode (ERDIS) there are two student learning activities, a description of the competencies in each learning activity is:

\section{Media Selection}

Selection of the right media to be presented in instructional. This process involves matching assignments and analysis, training target-participant characteristics, production sources, and dissemination plans with a variety of different media attributes. Based on the results of media selection analysis that has been done, it can be stated that the media needed and chosen to be used in implementing the Digital Entrepreneur learning model (ERDIS) are; 1) Teaching Modules with learning activities in each ERDIS project undertaken, 2) Using technology-based learning media, which is a website media to facilitate technology-based learning. Both of these media have been developed to support the application of the ERDIS learning model. 


\section{Initial Design}

Initial design through activities to adjust basic needs through appropriate models and media. Activities at this stage are structuring learning activities and completeness of learning. The results of the design carried out are on; 1) Learning Models, 2) Learning Modules, 3) Lecturer Teaching Guidelines, 4) Student Learning Guides, 5) ERDIS Model Websites. Structure of the ERDIS Learning Model

Adjusting to the learning needs of the 21st century and the ability of the new literacy era of the industrial revolution 4.0, the ERDIS learning model was developed with syntax which was prepared as a guideline for carrying out learning in stages. the syntax of the erdis model shown as figure 2 .

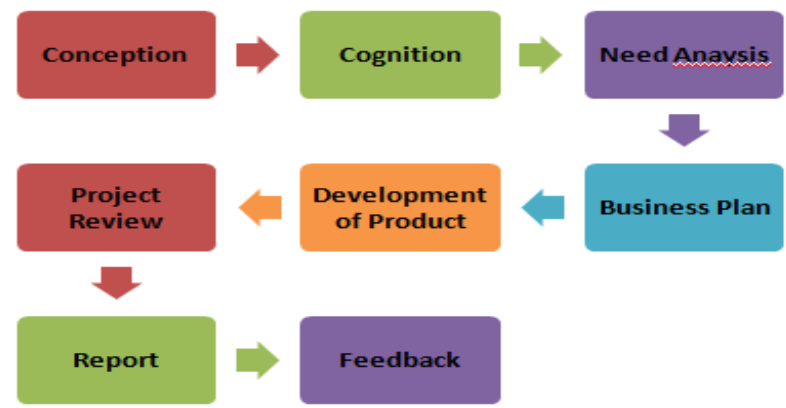

Fig. 2. Syntax of the Digital Entrepreneur Learning Model

Web learning based on ERDIS model is a learning media for lecturers and students in implementing the technology-based learning process to support the consolidation of big data literacy and technological literacy. The digital entrepreneur learning model website address is http://model-erdis.com/media/login.php. In implementing the ERDIS model the ERDIS model website is used, the process of sharing, uploading and downloading APSI learners is facilitated by the ERDIS model. Following is the appearance of the ERDIS model website shown as in figure 3.

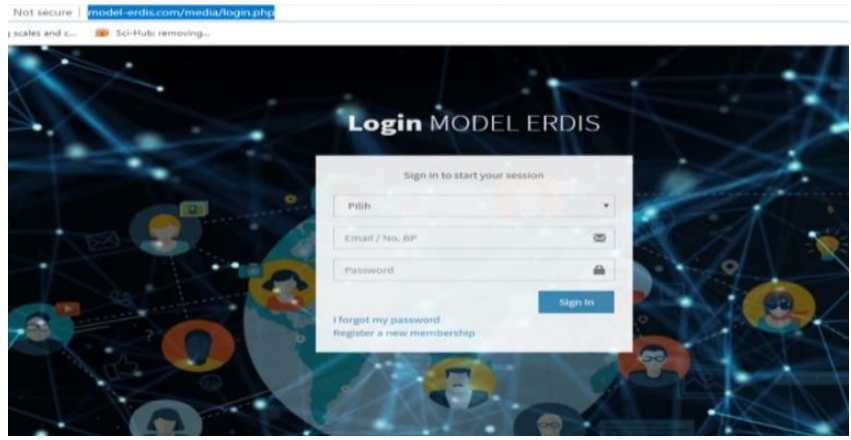

Fig.3.Login page for the ERDIS Model website

\section{Group Discussion Forum (FGD)}

The stages that must be passed after the initial design is to conduct FGDs to solicit expert and practitioner opinions about the product being developed. The results of the FGD were used as material to improve the design to be revised and prepared for trial. Based on the results of the FGDs that have been put forward by the experts, the model and the equipment model will be improved according to the recommendations. The results of the repair are then reconfirmed to the experts to check whether the product is in accordance with the suggested improvements. After going through the revision stage again for input after the FGD then the product is judged to the validator who concurrently experts when the FGD is conducted. The results of the validity analysis and trial are presented in the Develop section because the testing phase is part of that phase.

\section{Develop}

\section{Validity of Product}

Every instrument developed in a research must be tested first, aiming to ensure that the instrument has validity in terms of content. The results of the instrument testing carried out showed that the instruments that had been developed had an average score of $0.871>0.677$ which stated that the instrument had a valid value and was suitable for use in research. Previously the instrument had been improved based on expert opinion and input to improve the product.

The learning model that has been developed and improved in accordance with expert input was tested with 5 experts, all of whom were experts who provided input during the FGD. The results of testing the learning model carried out showed that the average score of $0.818>0.677$ which states that the model category is valid and feasible to be used in research.

The results of testing the phases of the learning model syntax conducted showed that the average score of 0.815> 0.677 which states that the model has valid categorical phases and is suitable for use in research. Other tests to assess the validation of the syntax phases in the ERDIS learning model are carried out using Confirmatory Factor Analysis or abbreviated as CFA. This stage intends to find out whether the phases that have been developed can confirm the construct of the model that has been developed as a whole. The following research report reports for the analysis of the validation of syntax based on the syntax model:

Analysis of the validation of the syntax construct of this model was performed using the LISREL 9.3 software program. The overall model assessment can be obtained based on the model suitability index (Goodness of fit statistics) produced by LISREL. The most common model accuracy index is the Chi-Square value [25](Joreskog \& Sorbom, 1993). To assess the fit model, it is expected that the Chi-Square value is not significant (p-value $>0.05$ ) because these results indicate that there is no difference between the model and the data. In addition, from these results we also meet with the interpretation of the loading factor. By definition loading factor is a large correlation between the indicator and its constructors.

A factor weight reference of 0.50 or more is considered to have a validation that is strong enough to explain the construct [26], [27].

The results of data analysis of the validation construct of the ERDIS learning model syntax can be seen in the figure 4 . Based on Figure 4 it can be seen that the p-value is 0.99946 meaning that the p-value is $>0.05$ so that the syntax of the model meets the criteria for goodness of fit models, so the construct validity is classified as fit or valid. In addition, based on the picture, it can be seen the results of each indicator of the latent variable have met the requirements of loading factors above 0.50 so that it can be accepted, meaning that the items used are good enough in measuring the syntax construct of the ERDIS learning model. 


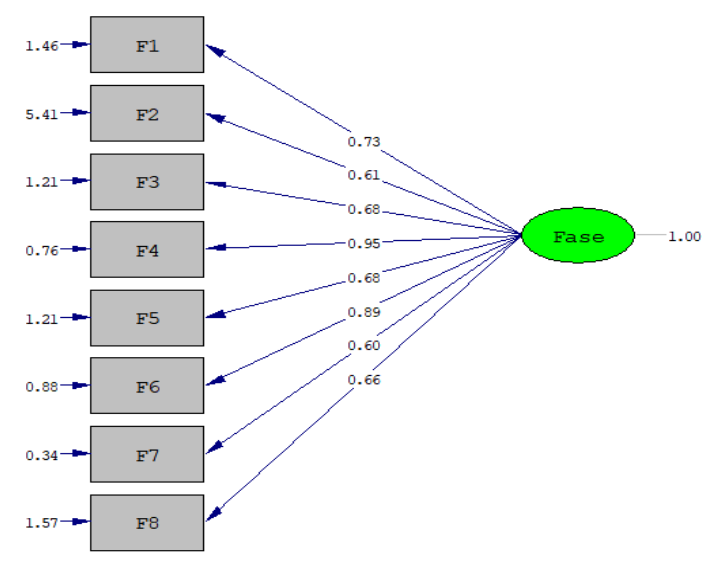

Fig.4. Validation of Constructions ERDIS Model Syntax

\section{Development testing}

Practicality assessment is done through filling out a questionnaire to 25 students of the experimental group and to 5 lecturers observing the learning process with the ERDIS model. Practicality test results showed an average practicality assessment of the application of the ERDIS learning model by $85 \%$ with the category of High practicality.

Practicality assessment is done through filling out a questionnaire to the experimental group students totaling 25 people who learn to use the ERDIS model. The following summarizes the results of the practicality analysis showing the average results of the practicality assessment of the application of the ERDIS learning model based on the perception of experimental class students by $82 \%$ with the category of High practicality.

The cognitive domain is the domain of knowledge students have after attending the learning process. To test whether there are different levels of student knowledge in the control and experimental groups an assessment is carried out through an objective test on the competencies that are each presented in module 1 and module 2 . The following results describe the data level of student knowledge:

Table 1 Description of Average Data Learning Outcomes of the Cognitive Domains

\begin{tabular}{|l|r|r|}
\hline \multicolumn{2}{|c|}{ Statistics } \\
\hline N $\quad$ Valid & Eksperimen & Kontrol \\
\hline \multicolumn{1}{|c|}{ Missing } & 25 & 25 \\
Mean & 0 & 0 \\
Median & 81.08 & 75.60 \\
Mode & 81.00 & 75.00 \\
Std. Deviation & 79 & 75 \\
Minimum & 5.283 & 6.564 \\
Maximum & 70 & 62 \\
Sum & 92 & 87 \\
\hline
\end{tabular}

Based on Table 1 above it is known that the average cognitive learning outcomes of the Experiment group $(\mathrm{N}=$ 25) amounted to 81.08 and the control group amounted to 75.60. The data was obtained from the sum of module 1 cognitive test results with an average score of 83 for the experimental group and 77 for the control group, while the results of the module 2 cognitive test obtained an average score of 80 for the experimental group and 73 for the control group. The description of cognitive learning outcomes shows that the experimental group has better learning outcomes than the control group.
Hypothesis testing for cognitive domain learning outcomes is performed using the independent sample $t$ test. The results of data normality show the Asimp score. the significance of the KS test (Kormogorov Smirnov) was 0.865 for the experimental group data and 0.891 for the control group data, meaning that the data was assumed to be normal (the results of data analysis can be seen in the appendix). Hypothesis testing shows the t-test score of 3,252> t table of 2,010 ( $\mathrm{df}=48$ ) which means that the Hypothesis $(\mathrm{Ha})$ which reads there are differences in cognitive domain learning outcomes in the experimental and control groups at a significance level of $95 \%$. The results of testing this hypothesis

The Affective Domain is the realm of attitude shown by students in following the learning process. To test whether there are different affective levels of students in the control and experimental groups an assessment is conducted through a Likert scale questionnaire referring to the assessment of the new literacy era of the industrial revolution 4.0, especially humanity literacy with C4 indicators namely critical thinking, creativity, communication and collaboration. The following is the average description of the affective domain learning outcomes based on humanity literacy behavior in the industrial revolution era 4.0:

Table 2 Learning Outcomes of Affective Domains
through Humanity Literacy assessment Statistics

\begin{tabular}{|l|r|r|}
\hline & Eksperimen & Kontrol \\
\hline N $\quad$ Valid $\quad$ Missing & 25 & 25 \\
Mean & 0 & 0 \\
Median & 82.24 & 67.68 \\
Mode & 85.00 & 66.00 \\
Std. Deviation & 85 & 73 \\
Minimum & 6.450 & 10.152 \\
Maximum & 66 & 54 \\
Sum & 91 & 87 \\
\hline
\end{tabular}

Based on Table 2 above it is known that the average affective domain learning outcomes based on humanity literacy Experiment group ( $\mathrm{N}=25$ ) of 82.24 and the control group of 67.68. The description of affective learning outcomes shows that the experimental group has better affective learning outcomes than the control group.

Hypothesis testing for affective domain learning outcomes is carried out using the independent sample t test. The results of data normality show the Asimp score. the significance of the KS test (Kormogorov Smirnov) was 0.355 for the experimental group data and 0.750 for the control group data, meaning that the data was assumed to be normal (the results of data analysis can be seen in the appendix). Hypothesis testing shows the t-count score of 3,688 $>\mathrm{t}$ table of 2,010 (df $=48$ ) which means that the Hypothesis ( $\mathrm{Ha})$ which reads there are differences in the learning outcomes of the affective domain in the experimental and control groups at a significance level of $95 \%$. The results of testing this hypothesis states that the ERDIS learning model is effective in optimizing affective learning outcomes. 
Learning outcomes in the psychomotor domain are assessed through assessments on the results of student practice in working on Digital Entrepreneur (ERDIS) projects 1 and 2 . The assessment is carried out on three project planning activities, project appraisal and project activities. Each assessment result shown as table 3:

Table. 3. Project Appraisal

\begin{tabular}{|c|c|c|c|c|c|c|}
\hline \multirow{2}{*}{ Group } & \multicolumn{2}{|c|}{ Project Planning } & \multicolumn{2}{c|}{ Project Result } & \multicolumn{2}{c|}{ Project Activity } \\
\cline { 2 - 7 } & Project 1 & Project 2 & Project 1 & Project 2 & Project 1 & Project 2 \\
\hline 1 & 84 & 92 & 85 & 95 & 76 & 93 \\
\hline 2 & 72 & 84 & 71 & 85 & 71 & 87 \\
\hline 3 & 80 & 92 & 87 & 78 & 87 & 84 \\
\hline 4 & 72 & 88 & 75 & 84 & 78 & 80 \\
\hline 5 & 92 & 92 & 89 & 93 & 93 & 93 \\
\hline Average & 90 & 81 & 87 & 81 & 87 & 90 \\
\hline \multicolumn{3}{|c|}{85,5} & \multicolumn{2}{|c|}{84} & \multicolumn{2}{c|}{88,5} \\
\hline
\end{tabular}

Psychomotor learning outcomes show that students who learn to use the ERDIS learning model who have worked on Digital Entrepreneur (ERDIS) 1 and 2 projects show a very good average ability in project planning 1 and good in project 2, project results 1 and 2 show the categories good and project activities 1 have good and very good results on project 2. Thus based on psychomotor learning outcomes show good average results on all aspects of the assessment assessment of digital entrepreneur projects. Thus the ERDIS learning model and model devices have effectiveness in optimizing psychomotor learning outcomes. For more details on psychomotor learning outcomes in each project can be seen in Figure 5.

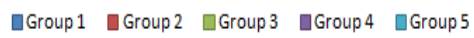

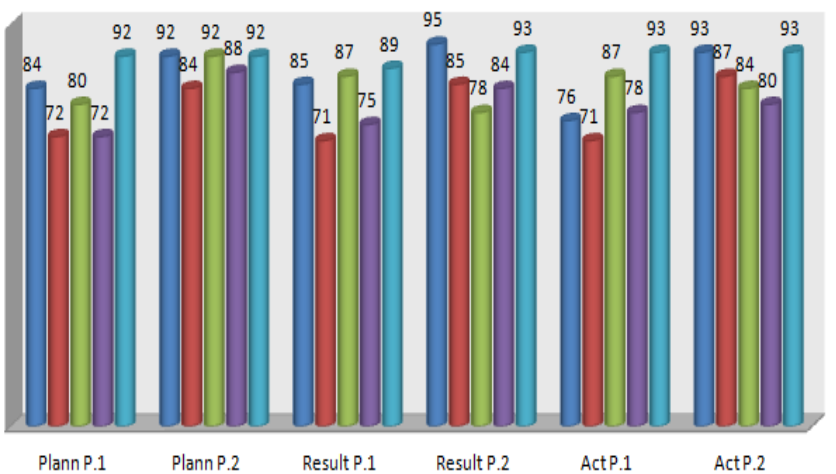

Fig. 5 Digital Entrepreneur Project Psychomotor Learning Outcomes

In a study of the development of learning models, the existence of the accompanying impact is an indicator of the novelty of a model. The accompaniment impact is a student's ability which is obtained as an impact in applying a learning model. The accompanying impact that is expected in implementing the Digital Entrepreneur learning model is the ability to carry out entrepreneurial activities through learning activities of APSI courses by applying literacy capabilities of the industrial revolution era 4.0, namely big data literacy, technology literacy and humanity literacy.

Accompaniment impact data is obtained through direct observation in the field when students do project 1 and project 2 in groups. The observations made can be seen in the following Table 4.
Table 4. Observation of New Literacy Capability of R.I 4.0

\begin{tabular}{|l|l|c|}
\hline \multicolumn{1}{|c|}{ Literasi } & \multicolumn{1}{|c|}{ Indicator } & Score \\
\hline Big data & Download, Upload, Sharing & 84 \\
\hline Technology & Media, technologi, Information & 84 \\
\hline \multirow{4}{*}{ Humanity } & Critical thinking & 77 \\
\cline { 2 - 3 } & Creativity & 86 \\
\cline { 2 - 3 } & Collaboration & 74 \\
\cline { 2 - 3 } & Communication & 81 \\
\hline \multicolumn{2}{|c|}{ Average } & 81 \\
\hline
\end{tabular}

The results of observations made to students who carry out learning activities for digital entrepreneur projects (ERDIS) 1 and 2 show the ability to apply the big data literacy activity that is shown by students when the project is carried out by students seeking information through the internet by downloading information. Students download the assignments given by the lecturers and upload assignments and reports via the website. The things that students do in this learning activity show that students have implemented the ability of big data literacy. Related to technology literacy, in the observations that have been made it can be explained that students make use of information media with a variety of technological media that can be accessed and operationalized. Students carry out business promotion activities using technology-based media, students direct the information obtained and sort the information before it is used, this shows that students already have the ability to assess technology-based information media by doing things wisely in using technology. It is known that students are already adept at using technology media, students can use digital tools in developing projects carried out, students carry out business promotion activities through technology-based media and show an attitude of understanding the benefits of using technology for entrepreneurship. Humanity literacy can be observed through learning activities shown by students in practice. Students demonstrate the ability to think critically through the reasoning of the project that will be chosen to be carried out, the critical thinking of students can be demonstrated through sensitivity to business opportunities that will be carried out. Thinking about the possible risks that can arise from the selection of business opportunities undertaken by students is shown in project selection and project planning. The creativity that arises in the form of ideas and ideas by optimizing the ability to create innovative ideas in developed businesses. When running a project students are trained to think of solutions to problems that arise during project work. Creativity thinking is shown to solve problems in completing projects. Communication skills seen in project activities become the main task of lecturers in directing. There is still a sense of wanting to show off in groups, as well as between groups, it seems that students are still not very capable of conflict management in solving peer problems. Students should be trained stronger in communication techniques in the environment and learning activities. While the collaborative ability of students seems to be able to contribute in learning. Oral and written communication through technology media has been demonstrated by students by training them to promote projects to the community through social media and their own websites or blogs. 
Collaboration shown by students in groups increases during project work, students better understand the function of collaboration in groups to achieve project goals and success.

\section{Disseminate}

The activities carried out at the Disseminate stage are Packeging and Diffusion. The following is an explanation of the two phases:

\section{Packaging}

After the development process is carried out, the next stage is packaging. This aims to perfect the development process that has been carried out for the dissemination stage of development results. However, in the research and development of the Digital Entrepreneur Learning Model (ERDIS) the packaging process is carried out limited to dissemination in the research class. Henceforth after conducting research and development with perfect stages, in the author's planning all development products will be published and packaged into ERDIS Model books and other ERDIS model kits through official publishers.

\section{Diffusion}

The final activity of the research and development stage in the Four D's framework is the Diffusion stage with the intention that the product that has been developed is otherwise widely accepted by the user, blending in with the existing learning model so that it becomes a new learning model that is accepted and adopted in learning activities. at vocational schools and colleges. This research is still waiting for the implementation process in the expansion of the results of the development carried out through the publication of research books and scientific journals.

\section{CONCLUSION}

The development of the ERDIS learning model shows the results that: 1) Define phase shows that the achievement of APSI courses has not been optimal due to the low use of the application of student practice results, the analysis of the need for learning of APSI $82 \%$ is categorized as high. 2) The design phase has been designed learning models and support systems through the stages of design, FGD, and revision, 3) Develop is the phase of testing the validity and practicality and effectiveness through the application of learning models in the experimental group, 4) Disseminate is the dissemination phase in this study conducted only limited to the experimental group as a research sample.

The results of testing the validity of each product development have the results: The quality of the instrument 0.871, the learning model 0.818, the ERDIS learning model book 0.806, the lecturer teaching guide book 0.803, the student learning manual book 0.805, the APSI teaching module an average 0.823 , the ERDIS model website 0.806 . The results of testing the validity of the results show that all products already have the results of product validity are at a score $>0.677$. The results of testing the practicality of the product according to students $82 \%$, based on the perception of lecturers $85 \%$ means the product has a high practicality. The results of the analysis of the effectiveness of the cognitive domain showed a t-test score of 3,252> t table of 2.010 which means that Hypothesis (Ha) was accepted, the affective domain hypothesis testing showed a t-count score of $3,688>$ t table of 2,010 which meant that Hypothesis (Ha) at the 95\% significance level . The results of research in the psychomotor domain through the ERDIS 1 and 2 project appraisal are in the Good category, this means the product is worth the effectiveness.

\section{ACKNOWLEDGMENT}

The authors would like to thank colleagues from the Faculty of Engineering, Universitas Negeri Padang and Universitas Putra Indonesia YPTK Padang for their support and advice in conducting this research

\section{REFERENCES}

1. M. C. Sahin, "Instructional design principles for 21 st century learning skills," Procedia - Soc. Behav. Sci., vol. 1, no. 1, pp. 1464-1468, 2009, doi: 10.1016/j.sbspro.2009.01.258.

2. A. Fernald, L. W. Jr, Solomon, G. T., \& Tarabishy, “A New Paradigm: Entrepreneurial Leadership,” Int. Res. J., vol. 30, no. 2, pp. 257-276, 2005.

3. A. Bagheri, "The impact of entrepreneurial leadership on innovation work behavior and opportunity recognition in high-technology SMEs,' J. High Technol. Manag. Res., vol. 28, no. 2, pp. 159-166, 2017, doi: 10.1016/j.hitech.2017.10.003.

4. B. Trilling and P. Hood, "Learning, Technology, and Education Reform in the Knowledge Age," Educ. Technol., p. 26, 1999.

5. R. Efendi, J. Jama, and A. Yulastri, "Development of Competency Based Learning Model in Learning Computer Networks," J. Phys. Conf. Ser., vol. 1387, no. 1, pp. 0-6, 2019, doi 10.1088/1742-6596/1387/1/012109.

6. T. M. Johan, Ambyar, J. Jama, R. Efendi, and M. Dewi, "Developing of MONAKI model on nursing information system to improve 21st century competencies," Int. J. Sci. Technol. Res., vol. 8, no. 11, pp. 1247-1251, 2019.

7. R. Efendi, A. Yulastri, and Yusran, "Implementation Competency Based Learning Model Of Learning Computer Network Courses At Vocational Education,” J. Adv. Res. Dyn. Control Syst., vol. 11, no. 5 , pp. 501-505, 2019.

8. A. Edmond, A. Oluniyi, and O. Bamidele, "Re-Engineering Technical Vocational Education And Training ( TVET ) Towards Safety Practice Skill Needs Of Sawmill Workers Against Workplace Hazards In Nigeria .," J. Educ. Pract., vol. 5, no. 7, pp. 150-157, 2014.

9. C. Christensen, S. Aaron, and W. Clark, "Disruption in education," Educ. Rev., vol. 38, no. 1, pp. 44-54, 2003.

10.F. Musa, N. Mufti, R. A. Latiff, and M. M. Amin, "Project-based Learning (PjBL): Inculcating Soft Skills in 21st Century Workplace," Procedia - Soc. Behav. Sci., vol. 59, no. 2006, pp. 565-573, 2012, doi: 10.1016/j.sbspro.2012.09.315.

11.C. L. Greene, 21st Century Business: Entrepreneurship. 2010.

12.N. E. Association, "Preparing 21st Century Students for a Global Society: An Educator's Guide to the "Four Cs," p. 38, 2010.

13.Unesco, UNESCO ICT Competency Framework for Teachers | OER Commons. 2018.

14.B. Trilling and C. Fadel, 21st Century Skills: Learning for Life in Our Times. Wiley, 2009.

15.Iskandar et al., "Competence improvement of visual basic programming through project-based learning," Int. J. Sci. Technol. Res., vol. 8, no. 9, pp. 1757-1760, 2019.

16.S. M. Drake and R. C. Burns, Meeting Standards Through Integrated Curriculum. Virginia USA: Association for Supervision and Curriculum Development, 2004.

17.W. A. Edmonds and T. D. Kennedy, An Applied Guide to Research Designs: Quantitative, Qualitative, and Mixed Methods. SAGE Publications, 2016.

18.B. R. Joyce, M. Weil, and E. Calhoun, Models of Teaching. Pearson Education, 2017.

19.W. Prima, Ganefri, Krismadinata, and R. Hayati, "Improving A Quality Of Services Through Information System Model Of Academic Services Based On Customer Relationship Management At University,” Int. J. Eng. Adv. Technol., vol. 8, no. 6, pp. 2500-2505, 2019, doi: 10.35940/ijeat.f8561.088619. 
20.G. B. Willis, Analysis of the Cognitive Interview in Questionnaire Design. Oxford University Press, 2015.

21.S. B. Merriam and E. J. Tisdell, Qualitative Research: A Guide to Design and Implementation. Wiley, 2015.

22.J. Saldana and M. Omasta, Qualitative Research: Analyzing Life. SAGE Publications, 2017.

23.L. J. Moleong, Metodologi Penelitian Kualitatif (Edisi Revisi). Jakarta: Remaja Rosdakarya, 2017.

24.M. Freeman, Modes of Thinking for Qualitative Data Analysis. Taylor \& Francis, 2016.

25.K. G. Jöreskog and D. Sörbom, LISREL 8: Structural Equation Modeling with the SIMPLIS Command Language. Scientific Software International, 1993.

26.J. F. Hair, W. C. Black, B. J. Babin, and R. E. Anderson, Multivariate Data Analysis. Pearson Education Limited, 2013.

27.I. Ghozali, Model persamaan struktural: konsep dan aplikasi dengan program Amos 16.0. Badan Penerbit Universitas Diponegoro, 2008.

\section{AUTHORS PROFILE}

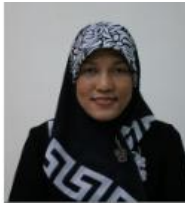

Erdisna bachelor degree of system information in 1996 then master information system in 2006 from Universitas Putra Indonesia (YPTK) Padang. She is a candidate doctor of engineering and vocational education at Padang State University, West Sumatera, Indonesia. This research focuses on the development entrpreneur digital learning.

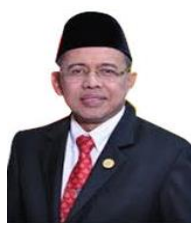

Ganefri received bachelor degree of education from Universitas Negeri Padang in 1988 and Master of Education from Universitas Negeri Yogyakarta in 1996, then Ph.D from Universitas Kebangsaan Malaysia. He is a lecturer in electrical engineering at Universitas Negeri Padang and he is also a professor at Universitas Negeri Padang.

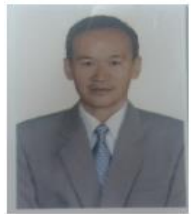

Ridwan received bachelor degree of education from Universitas Negeri Padang in 1979 and Master of Sciencen from State University Of New York At Oswego in 1986, then Doctoral from Universitas Negeri Malang. He is a lecturer in electrical engineering at Universitas Negeri Padang .

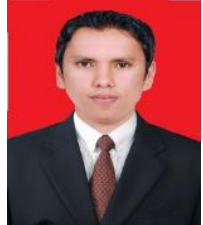

Raimon Efendi bachelor degree of business administration in 2008, then master information system in 2011 from Universitas Putra Indonesia (YPTK) Padang. $\mathrm{He}$ is doctor of vocational education in 2019 from Universitas Negeri Padang. He is a lecturer at Universitas Dharmas Indonesia, West Sumatera, Indonesia. This research focuses is the implementation of web media on learning. 